\title{
Effects of oxygen depletion on the ecology, blood physiology and fishery of the Norway lobster Nephrops norvegicus
}

\author{
Susanne P. Baden, Leif Pihl, Rutger Rosenberg \\ University of Göteborg, Marine Research Station at Kristineberg, S-450 34 Fiskebäckskil, Sweden
}

\begin{abstract}
Biomass, population structure, food selection and blood (haemolymph) physiology of the Norway lobster Nephrops norvegicus (L.) were investigated in SE Kattegat, an area where low oxygen concentrations ( $<2 \mathrm{ml} \mathrm{l}^{-1}, 30 \% \mathrm{O}_{2}$-saturation) have occurred in the bottom water for 1 to 3 mo periods in most years in the 1980 's. During the study period (October 1984 to September 1989) lobster biomass decreased in the area from $10.8 \mathrm{~kg} \mathrm{~h}^{-1}$ (catch per unit effort) to zero (estimated during the last 12 mo of the investigation). Males contributed on average $78 \%$ of the population density, except in September 1988 during severe hypoxia when a reversed sex ratio was found and females (even berried) dominated ( $75 \%$ of density). The food of $N$. norvegicus belonged to 4 major groups; crustaceans, echinoderms molluscs and polychaetes. The dominant species eaten within these groups were also found to be dominants in the benthic infauna. This suggests that $N$. norvegicus are not feeding selectively but taking available organisms indiscriminately. In the field and in laboratory experiments $N$. norvegicus increased blood pigment (haemocyanin, $\mathrm{Hcy}$ ) concentration in moderate hypoxia $\left(20\right.$ to $40 \% \mathrm{O}_{2}$ saturation), and reduced it in severe hypoxia (10 to $20 \% \mathrm{O}_{2}$-saturation). At $\mathrm{O}_{2}$-saturations below $15 \%$ $N$. norvegicus ceased feeding and had empty stomachs. Thus in low oxygen concentrations the lobsters suffer from hypoxia-induced starvation rather than lack of food. Survival of $N$. norvegicus exposed to 15 and $10 \% \mathrm{O}_{2}$-saturation was $4 \mathrm{wk}$ and 2 to $4 \mathrm{~d}$, respectively. After return to normoxia recovery of blood Hcy concentration was slow, probably due to lack of copper in the diet, which is essential for Hcy synthesis. We consider blood Hcy concentration to be a promising 'in situ' biomarker with ecological relevance.
\end{abstract}

\section{INTRODUCTION}

The Kattegat is shallow (mean depth $23 \mathrm{~m}$ ) and has a strong halocline at 15 to $20 \mathrm{~m}$ depth during summer and autumn, which makes the area below the halocline susceptible to oxygen deficiency due to eutrophication. Between 1980 and 1989 oxygen deficiency has occurred in the bottom water during autumn in most years in the southern part of the Kattegat and has increased progressively in space and time causing adverse effects on the benthic macro- and mega-fauna and on demersal fish (Rosenberg 1985, Hagerman \& Baden 1988 , Rosenberg \& Loo 1988, Pihl 1989). Dead and dying Norway lobsters Nephrops norvegicus (L.) were first reported by fishermen in the southern Kattegat in October 1985. In 1988 the oxygen deficiency was more serious $\left(\mathrm{O}_{2}<1 \mathrm{ml} \mathrm{l}^{-1}, 15 \% \mathrm{O}_{2}\right.$-saturation), lasted for a longer time and extended to an area of about $4000 \mathrm{~km}^{2}$. Few fish and no lobsters were caught in this area for at least 3 mo during that year.
Investigations on the effects of eutrophication on Nephrops norvegicus were carried out between 1984 and 1989. The aims of these investigations were to (1) make field observations on changes and interactions in lobster biomass, population structure and feeding, (2) study changes in blood (haemolymph) pigment concentration in response to hypoxia $\left(\mathrm{O}_{2}<20 \%\right.$ saturation) in the SE Kattegat and, (3) evaluate the use of blood haemocyanin concentration of lobsters as an 'in situ' biomarker of hypoxia in the Kattegat and Skagerrak and in experimental studies.

\section{AREA INVESTIGATED}

A $3000 \mathrm{~km}^{2}$ area in the SE Kattegat at 25 to $50 \mathrm{~m}$ depth and with a soft sediment bottom was investigated (Fig. 1). The sediment structure in the area is silty-mud with a content of organic matter (ignition loss) of about 13 to $15 \%$ (Rosenberg \& Loo 1988). The 


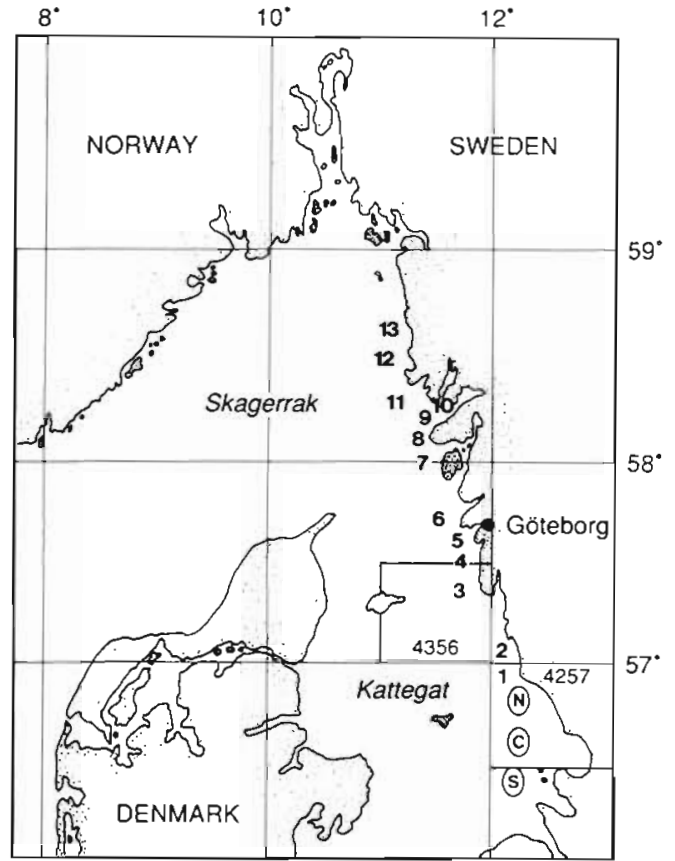

Fig. 1. The sampling subareas (N: north, $\mathrm{C}$ : center and $\mathrm{S}$ : south) in the SE Kattegat in which research trawling for Nephrops norvegicus has been carried out at 8 to 12 stations from 1984 to 1989. N. norvegicus from Stations 1 to 13 in the northern Kattegat and in the Skagerrak were collected by commercial trawlers for blood sampling, except for Station 9 near the Marine Research Station at Kristineberg, where monthly samples through a year were obtained with lobster creels. The areas 4257 and 4356 are 2 subareas from which commercial catch statistics are collected by ICES (International Council for Exploration of the Seas)

water mass is characterized by a strong vertical stratification with the halocline normally situated at 15 to $20 \mathrm{~m}$ depth. Surface salinity varies between 15 and $25 \%$ and below the halocline between 32 and $34 \%$. During summer stratification is even stronger as a thermocline also develops. Surface water temperature varies from 10 to $20^{\circ} \mathrm{C}$ in summer and 0 to $10^{\circ} \mathrm{C}$ in winter. Bottom water temperature is 4 to $12{ }^{\circ} \mathrm{C}$, with highest values in late summer and autumn. Tidal amplitude is about $0.1 \mathrm{~m}$ (Svansson 1975).

In the Skagerrak Nephrops norvegicus were obtained from muddy coastal stations at depths of 33 to $60 \mathrm{~m}$. Bottom water salinities and temperatures were similar to those found in the Kattegat.

\section{MATERIALS AND METHODS}

Sampling. Nephrops norvegicus in the SE Kattegat were sampled in subareas $N, C, S$ (Fig. 1) by research vessels using a Glommen lobster trawl (ground rope $86 \mathrm{~m}$, head rope $76 \mathrm{~m}$, sweep $55 \mathrm{~m}$ and otter board $2.2 \mathrm{~m}$ ) with a mesh size of $60 \mathrm{~mm}$ in the cod end.
Samples were taken in spring (April) and in autumn (September to December) during each year from 1984 to 1989 . In general 8 to 12 trawl samples (duration 30 mini speed 3 knots) were taken on each occasion during daytime. Lobsters were counted, weighed, measured (tip of rostrum to telson) and sexed on board. In the NE Kattegat and the Skagerrak $N$. norvegicus were sampled (Stns 1 to 8,10 to 13 ; Fig. 1) by lobster trawl from commercial boats and for experimental work they were creel-caught near the research station (Stn 9; Fig. 1).

Oxygen concentration in the Kattegat was determined on most sampling occasions during 1985 to 1989. Measurements were made every $1 \mathrm{~m}$ below, and every $5 \mathrm{~m}$ above the halocline. At the bottom the measurement was made less than $0.5 \mathrm{~m}$ above the sediment surface. An air and Winkler calibrated Yellow Springs Instruments model YSI-58 oxygen meter was used. On 6 occasions additional Winkler titrations were made simultaneously on samples taken close $(10 \mathrm{~cm})$ to the bottom. Deviations between YSI-meter measurements and Winkler titrations were in general $<0.1 \mathrm{ml}^{-1}$. In the Skagerrak oxygen was measured only at Stn 9 by Winkler titration (Lindahl pers. comm.).

Blood, stomach and gill analysis. Nephrops norvegicus caught in SE Kattegat during the period October 1986 to September 1988 were analysed for blood pigment (haemocyanin, Hcy) concentration (only lobsters in the intermoult stage) and stomach content. Twenty specimens (if possible) from each trawl station were analysed. In the Skagerrak blood samples were also taken at 2 stations in the period November 1987 to November 1988. In addition, blood samples were taken from Skagerrak lobsters found dying in creels or when emerging from the sediment and caught in an anchorseine net. Blood samples were obtained from $N$. norvegicus caught in areas not subjected to low oxygen conditions in the Moray Firth, eastern Scotland, January 1987 (Hagerman \& Baden 1988) and from Loch Torridon, western Scotland in September 1988. The latter population of lobsters had never been commercially fished.

Samples of prebranchial blood were taken with hypodermic syringes $(0.3$ to $0.5 \mathrm{ml})$ from the arthrodial membrane at the base of the fifth leg as soon as possible after capture. The blood was diluted to double volume with distilled water to prevent clotting, frozen and returned to the laboratory. The influence of freezing for a period of $1 \mathrm{wk}$ was tested by Hagerman \& Baden (1988) and shown to give $<5 \%$ reduction of the Hcy concentration. When thawed a $200 \mu$ sample was diluted with $1 \mathrm{ml}$ distilled water in a $10 \mathrm{~mm}$ quartz cuvette and the absorbance measured at $339 \mathrm{~nm}$, using a Shimadzu spectrophotometer UV 2100. An extinction coefficient of $E_{1 \mathrm{~cm}}^{\mathrm{mM}}=17.26$ was used. This $E_{1 \mathrm{~cm}}^{\mathrm{mM}}$ value 
was calculated from $E_{1}^{1 \%} \mathrm{~cm}=2.83$ given by Nickerson \& van Holde (1971) and Antonini \& Brunori (1974) on the basis of a functional subunit of haemocyanin with a molecular weight of $74 \times 10^{3}$.

The weight of the stomach contents (frozen) was recorded and its constituents analysed to species or larger unit. In 1988 the occurrence of dark and black gills was recorded in Nephrops norvegicus from both the Kattegat and the Skagerrak.

Experimental analysis of changes in haemocyanin levels related to food and oxygen. The rate of changes in Hcy in Nephrops norvegicus exposed to different food conditions and oxygen tensions were studied in tanks of base area $1 \mathrm{~m}^{2}$, each containing 300 to $400 \mathrm{l}$ of seawater. To prevent turbidity when catching the $N$. norvegicus for the blood sampling, sand instead of mud was used as a substrate and the lobsters were provided with artificial plastic burrows. To mimic the natural light conditions at $40 \mathrm{~m}$ depth, the tanks were illuminated by green light using a 9:15 h day/night cycle.

Food: Experiments were carried out at different times of the year, and at different regimes. Expt 1 lasted from December 1987 to January 1988 (40 d) with temperatures between 7 and $9.5^{\circ} \mathrm{C}$. Expt 2 lasted from February 1988 to April 1988 (81 d) with temperatures of 4 to $6{ }^{\circ} \mathrm{C}$. As the water was pumped from $40 \mathrm{~m}$ depth in a flow-through system the temperature varied as in nature. Each experiment comprised 3 basins containing 4 to 7 Nephrops norvegicus of differing size and sex. In one of the basins $N$. norvegicus were starved, while in the second and third basins they were offered shrimps Pandalus borealis L. and brittle stars Amphiura/Ophiura spp. respectively, daily and in constant and generous amounts $(2 \mathrm{~g} w w$ per $N$. norvegicus). Surplus non-eaten food was recorded and removed. According to stomach content analysis of field-captured lobsters, polychaetes and molluscs are also eaten by $N$. norvegicus. In a pilot test, these prey groups [mainly Mytilus edulis (L.) and Glycera alba (L.)] were offered both live and dead but not accepted.

Oxygen: Two experiments with Nephrops norvegicus in hypoxic conditions were carried out in January to April 1989. Four tanks of base area $1 \mathrm{~m}^{2}$ were used, two with $100 \% \mathrm{O}_{2}$-saturation (controls) and two with reduced oxygen concentrations 10 and $20 \%$ in Expt $3 ; 12$ and $15 \%$ saturation in Expt 4$)$. The control series of $N$. norvegicus showed the same percentage change of Hcy in the 2 experiments (these are combined in Fig. 7). Nine intermoult stage $N$. norvegicus were held in each tank. Nitrogen was used to reduce oxygen and air bubbling to provide full oxygen. Gaseous control occurred in $2 \mathrm{~m}$ high and $0.3 \mathrm{~m}$ wide cylinders separate from the experimental tanks. The water was recirculated, and to reduce accumulation of ammonium, $10 \%$ of the volume was changed every other day. The increase of the oxygen concentration caused by change of water was small and returned to the former value within $1 \mathrm{~h}$. Stable oxygen tensions in the hypoxic tanks were obtained using an oxygen regulator (E. Larsen, University of Arhus), connected to an YSI-oxygen meter. The oxygen meter was connected to the outflow of a submersible water pump circulating the water in the tank. A piece of copper wire near the electrode prevented microbial growth on the membrane. Winkler titration was carried out every third day to calibrate the YSI-oxygen meter. The temperature during the experiments was 8 to $10^{\circ} \mathrm{C}$. The lobsters were fed before but not during the experiments. $N$. norvegicus in hypoxic water were occasionally offered a small amount of food to test for appetite. Blood samples were taken every 3 rd to 14 th day.

Statistical analysis. Differences in Hcy concentrations were tested using non-parametric statistics since the variance of compared series were found to be non-homogeneous when tested by Hartley's F max test (Zar 1984). Mann-Whitney's U-test was used between 2 independent series and the Kruskall-Wallis (KW test) 1 -way analysis of variance between 3 independent series (Zar 1984). When the $\mathrm{H}_{0}$ hypothesis of the Kruskall-Wallis test was rejected a posteri analysis of differences was carried out with a non-parametric multiple comparison test (NMC test) (Zar 1984). Since the samples in the low oxygen experiments were related, the non-parametric Wilcoxon matched-pairs signed-ranks test was used to test changes in haemocyanin concentrations (Zar 1984). The criterion for significance was $\mathrm{p}<0.05$

\section{RESULTS}

\section{Oxygen concentration}

The seasonal variation in the mean oxygen concentration of the bottom water in the study area is shown for the period August 1986 to September 1989 in Fig. 2A. Low oxygen values $\left(\mathrm{O}_{2}<2 \mathrm{ml} \mathrm{l}^{-1}\right)$ were recorded for 1 to 3 mo during autumn each year. The oxygen concentrations generally decreased with increasing depth on all sampling occasions, and the depth distribution is given for subarea $C$ in the period August to December 1988 (Fig. 2B). The study area in the SE Kattegat was divided into 3 sub-areas (Fig. 1) based on the frequency of oxygen deficiencies in the bottom water since 1981 (Table 1). The northern subarea has been affected by low oxygen $\left(\mathrm{O}_{2}<2 \mathrm{ml} \mathrm{l}^{-1}\right)$ during autumn in 6 out of $8 \mathrm{yr}$, the southern subarea in 5 out of $8 \mathrm{yr}$ and the central subarea only in the last $3 \mathrm{yr}$. The oxygen concentrations at Stns 1 to 13 are not known, except at $\operatorname{Stn} 9$. 


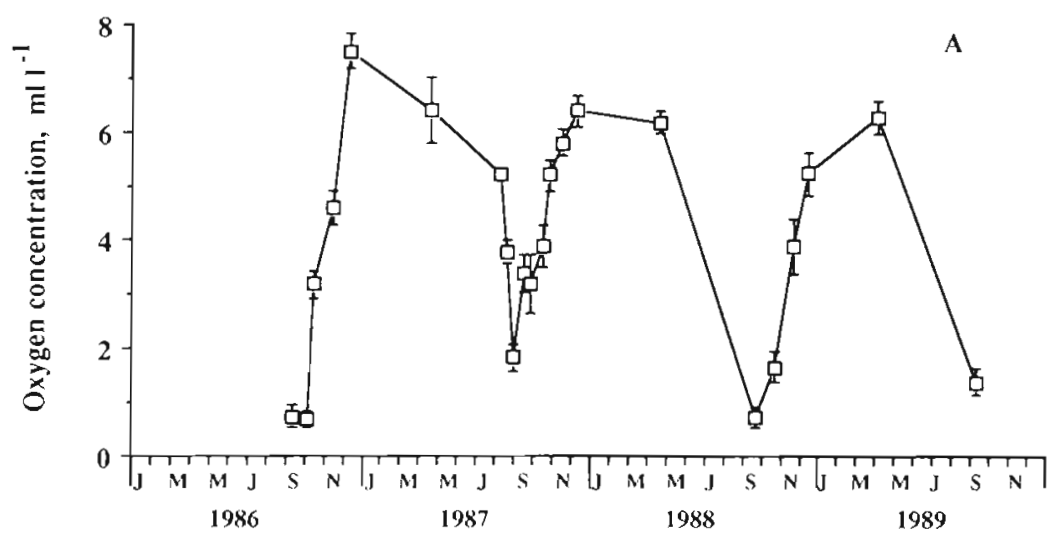

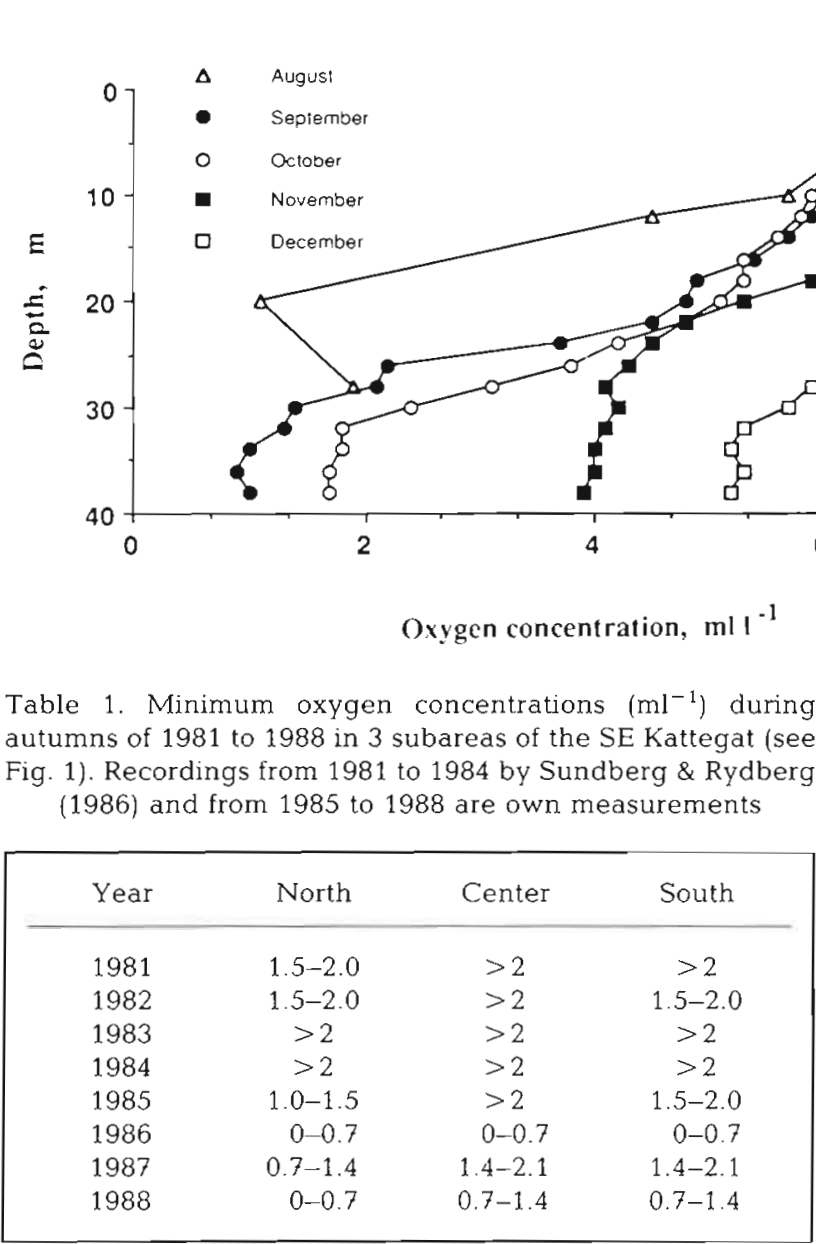

\section{Biomass}

The mean biomass of Nephrops norvegicus found was estimated between 0 and $10.8 \mathrm{~kg}$ (wet weight) per hour trawling in the area investigated (Fig. 3). During spring low biomasses were recorded each year. The highest biomass was recorded in November 1984. In 1985 and 1986 the biomass had decreased to between
0.8 and $2.3 \mathrm{~kg} \mathrm{~h}^{-1}$. During the autumn of these years large quantities of dead lobster (up to $50 \%$ of the total catch) were caught by Danish and Swedish fishermen in the area investigated. In the autumn of 1987 a higher biomass $\left(3.3\right.$ to $5.0 \mathrm{~kg} \mathrm{~h}^{-1}$ ) was observed compared to the 2 previous years. In September 1988 the mean biomass at the 12 stations was $3.5 \mathrm{~kg} \mathrm{~h}^{-1}$, but in the following $3 \mathrm{mo}$ and in April and September 1989 no lobsters were caught at these stations.

\section{Population structure}

The length frequency distribution and the sex ratio of the Nephrops norvegicus population is given for the 3 sub-areas in Fig. 4. The length distribution and the mean total length were similar in the 3 sub-areas on all sampling occasions and there was no clear change in distribution during the investigation. The sex ratio was about the same in the sub-areas during the period 1984 to 1987 where the percentage of males varied from 62 to $93($ mean $=78, \mathrm{SD}=8.2, \mathrm{n}=20)$. Females in the catch were mainly small and non-berried. However, in September 1988 a reverse in the sex ratio was observed 
Fig. 3. Nephrops norvegicus. Biomass given as trawl catch (mean and standard deviation, wet wt) per unit effort (CPUE, $\mathrm{kg} \mathrm{h}^{-1}$ ), in the study area in the SE Kattegat during 1984 to 1989. Each estimate is based on 8 to 12 samples. except in August 1986 and August 1987 when

5 and 3 samples were taken, respectively

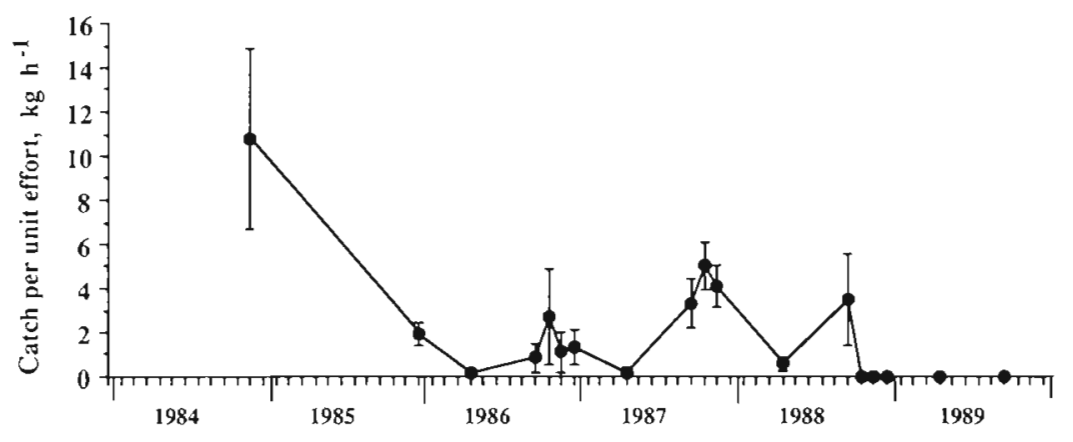

in the central and southern sub-areas with males only contributing between 23 and $26 \%$ of the total. During this sampling, low $\left(<1 \mathrm{ml} \mathrm{l}^{-1}, 15 \% \mathrm{O}_{2}\right.$-saturation) oxygen concentrations were recorded, which might have forced the females (even berried individuals) to leave their burrows. In the northern sub-areas only dead $N$. norvegicus were found on this sampling occasion.

\section{Catch statistics}

Annual mean of reported catches [catch per unit effort (CPUE), $\mathrm{kg} \mathrm{h}^{-1}$ ] of Nephrops norvegicus in the Swedish fishery was assessed during the period 1978 to 1988 in 2 ICES squares (4356 and 4257) in the E Kattegat (Figs. 1 and 5). ICES square 4356 covers the NE Kattegat and 4257 the SE Kattegat, including most of the area studied in this investigation. During the period 1978 to 1982 an increase in CPUE was observed in both areas, especially 4257, followed by a decrease. The year-to-year variation in CPUE (expressed as coefficient to variation) was calculated to be $47 \%$ in 4257, which is about $2 \frac{1}{2} 2$ times higher than in 4356 . In 1988 the overall CPUE was dominated by the catch in September, when a high mean CPUE of $10 \mathrm{~kg} \mathrm{~h}^{-1}$ was recorded, coinciding with the beginning of the hypoxic period when the $N$. norvegicus are emerging from the sediment. Very low CPUE values $\left(<2 \mathrm{~kg} \mathrm{~h}^{-1}\right)$ were recorded later in the autumn of that year.

\section{Lobster diet}

No differences in diet of Nephrops norvegicus were found between the subareas, so the data for the SE Kattegat were pooled. All together 35 different food items were found in the stomachs of $N$. norvegicus (Table 2). This is a minimum number because the food was masticated and difficult to identify. The identified species belong to 4 major groups; crustaceans, echinoderms, molluscs and polychaetes.

The 4 groups were all represented in an average of 46 to $66 \%$ of the stomachs (Table 2). Amphiura spp. and Ophiura spp. could not always be separated and were therefore pooled. They occurred together with Abra spp. in a high percentage of the stomachs. Other species which commonly occurred were Diastylis spp., Nucula spp., Glycera spp. and Pectinaria spp. The method of using percentage occurrence only gives an indication of the most important food items. Species such as Pagurus bernhardus (L.) and $N$. norvegicus and rapidly digested polychaetes will be underestimated. When present in the stomachs $P$. bernhardus and $N$. norvegicus represented most of the food taken, whereas small animals such as Diastylis spp. made up only a small proportion. Sometimes black deposits, presumably due to melanosis, were seen on remnants of $P$. bernhardus and $N$. norvegicus indicating that they could have been dead when eaten. $N$. norvegicus were mainly eaten in October 1986 and 1987 after periods of low oxygen in the bottom water.

The variation in frequency of occurrence of the 4 groups during the 2 yr study period (October 1986 to September 1988) was approximately the same with a maximum in April 1988 and a minimum in September 1988 (Table 2). Amphiura/Ophiura, Abra spp. and ostracods occurred in highest percentages in the stomachs during spring 1988. The low figures in September 1988 arose because most of the stomachs were empty at that time. If not empty, the stomachs of many berried females contained eggs from their pleopods and spines from Brissopsis lyrifera (Forbes). These spines were also found among the eggs on the pleopods. The mean ratio between the weight of the stomach contents and the overall body weight ranged from 0.8 to $1.2 \%$ during the period October 1986 to April 1988 and showed no seasonal pattern (Table 2). However, in September 1988 the ratio was very small (only $0.1 \%$ ).

Stomach analysis of lobsters caught near Stns 3 and 4 in the NE Kattegat in 1988 again showed that the diet, as in the SE Kattegat, comprised the same 4 groups: crustaceans, echinoderms, molluscs and polychaetes (Table 2). However, in this area crustaceans were found more frequently in the stomachs compared to the SE Kattegat. The hermit crab Pagurus bernhardus was 
NORTH

CENTER

SOUTH

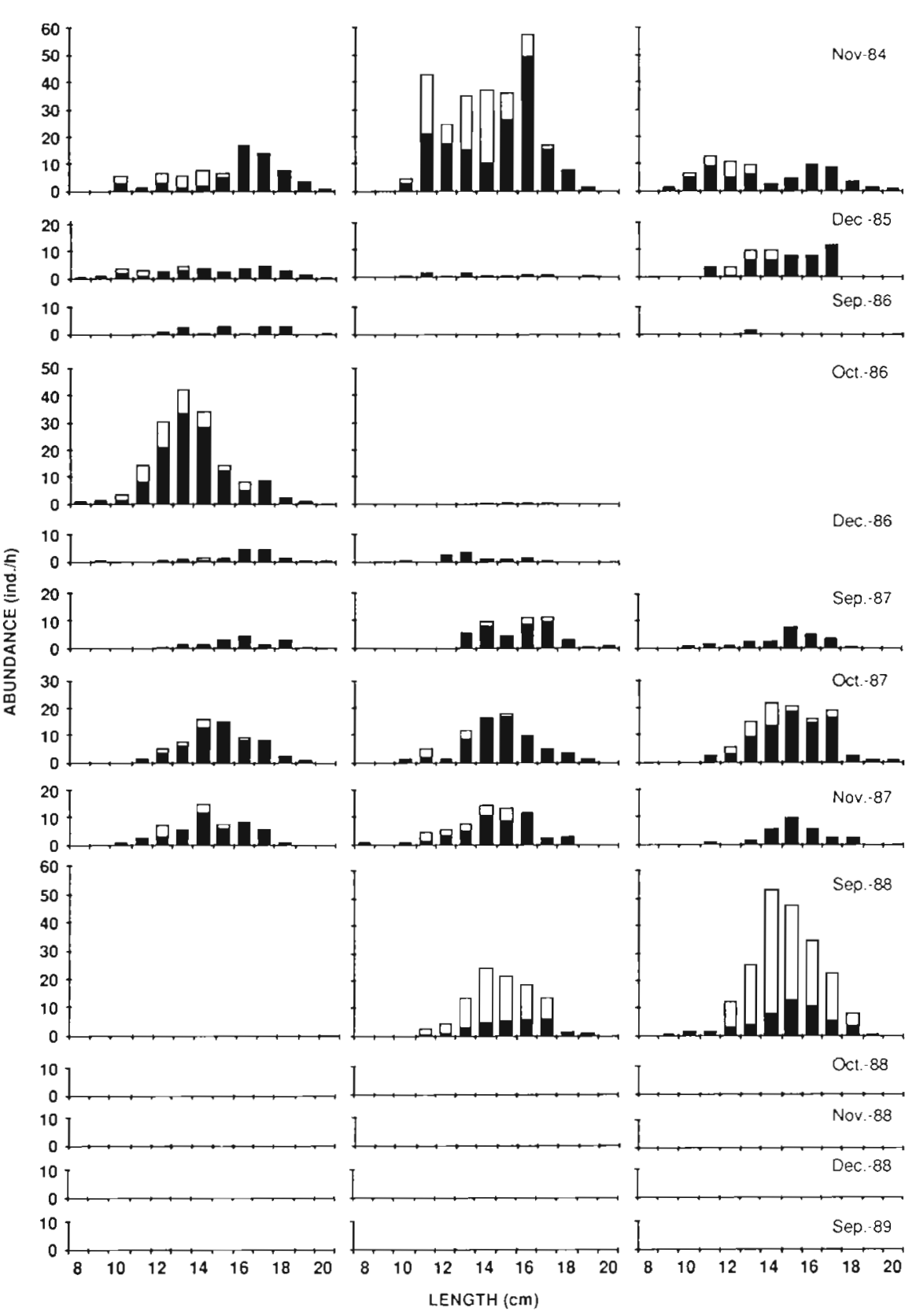

Fig. 4. Nephrops norvegicus. Length frequency distribution (CPUE, ind. $\mathrm{h}^{-1}$ ) of the population caught in the northern, central and southern subarea in the SE Kattegat during the period November 1984 to September 1989. Relative proportions of males (filled bars) and females (open bars) are given for each size class (total length in $\mathrm{cm}$ ). Where no bars are given no lobsters were found scarcer in the stomachs from the NE Kattegat compared to in the SE Kattegat, perhaps because the low oxygen concentration in the SE Kattegat had forced the crabs to leave their shells and thus increased their exposure to predation.

Haemocyanin concentration and discoloured gills: field observations

\section{Kattegat}

From October 1986 to December 1988 the blood Hcy concentrations of Nephrops norvegicus in the Kattegat were generally low (Fig. 6A). In October 1986 low $<0.11 \mathrm{mM}$ ) Hcy concentrations were found in lobsters from all subareas. The level of Hcy under normoxic field conditions was found to be between 0.4 and 1.0 $\mathrm{mM}$, e.g. in $N$. norvegicus in Scottish waters (Hagerman \& Baden 1988), corresponding to an oxygen-carrying capacity of the blood of 1.0 to 3.0 vol. $\mathrm{O}_{2} \%$ for most decapods (Mangum 1983). In subarea S the Hcy concentration in October 1986 was significantly $(p<0.001$, NMC test) lower than in the other subareas. However, in December 1986 concentrations in lobsters from subarea $\mathrm{S}$ had increased significantly $(\mathrm{p}<0.001$, U-test) 
Fig. 5. Nephrops norvegicus. Catch per unit effort $\left(\mathrm{kg} \mathrm{h}^{-1}\right)$ for lobsters taken in lobster trawl by Swedish fishermen in ICES areas 4257 and 4356 (see Fig. 1) in the E Kattegat during the period 1978 to 1988

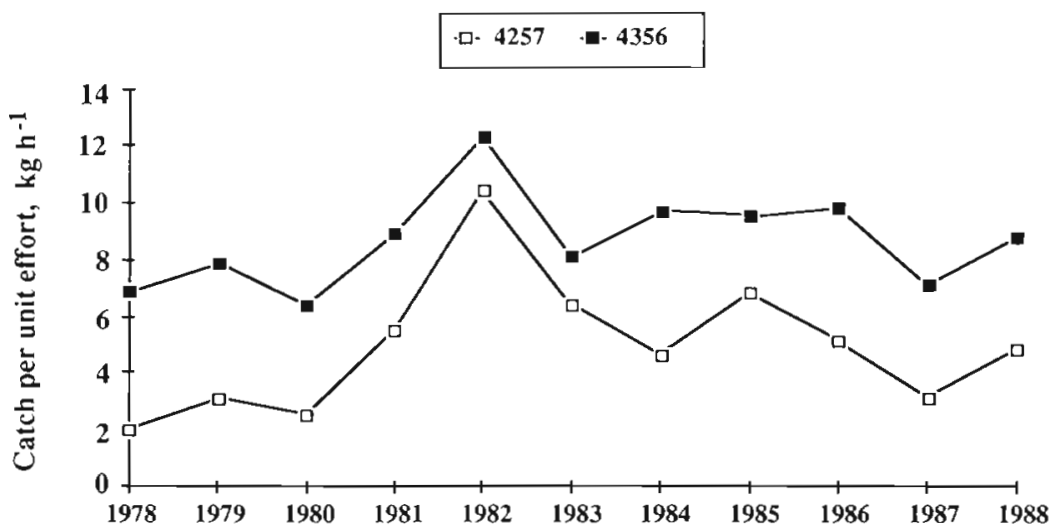

to 'normal' Hcy concentration ( $>0.6 \mathrm{mM}$ ). This was not the case in the northern and central areas, where no significant $(\mathrm{p}<0.05$, U-tests $)$ recovery took place.

In September, October and November 1987 the Hcy concentrations were $<0.2 \mathrm{mM}$ (Fig. 6A) and no significant ( $p>0.05$, KW test) difference was found between the subareas in September and October when compared at the same month. In November, however, significant differences in blood pigment were observed between all subareas ( $p<0.005$, NMC tests) with the lowest value in the northern subarea. During the autumn 1987 lobster Hcy concentration increased significantly ( $\mathrm{p}<0.001, \mathrm{KW}$ test) in the northern and central subarea, however not to 'normal' values, while no increase ( $p>0.05$, KW test) occurred in the southern subareas. In the central subarea the increase was significant ( $p<0.001, N M C$ test) between September and October while in the northern subarea a significant increase in blood pigment took place both between September and October ( $p<0.005, N M C$ test) and between October and November ( $p<0.001$, NMC test).

From November 1987 to April 1988, only the Nephrops norvegicus from subarea $\mathrm{S}$ showed a slight but significant increase ( $p<0.005$, U-test) in Hcy concentration after return to normoxic conditions in the bottom water (Fig. 6A). Between April and September 1988 the levels of haemocyanin in lobsters from subarea $\mathrm{C}$ increased significantly $(\mathrm{p}<0.001$, U-test) to 'normal' level (mean $=0.5 \mathrm{mM})$, but this recovery did not occur in subarea $S$. In the northern subarea only dead $N$. norvegicus were caught in September 1988.

Comparing the Hcy levels of $N$. norvegicus during the same months but from different years, significant differences were found in subareas $C$ ( $p<0.01$, U-test) and $\mathrm{S}$ ( $\mathrm{p}<$, U-test) from October 1986 to October 1987 , but not in subarea $N$, and from September 1987 to September 1988 in subarea $C(p<0.001, U$-test $)$ and $S$ $(\mathrm{p}<0.001$, U-test).

\section{Skagerrak}

The temporal change in Hcy concentrations of Nephrops norvegicus during November 1987 to November 1988 at Stn 9 ( $45 \mathrm{~m}$ depth) in the Skagerrak is shown in Fig. 6B. Monthly mean levels of Hcy concentration were between 0.4 to $1.2 \mathrm{mM}$. In August and September 1987 oxygen concentrations in the bottom water were around $3.5 \mathrm{ml} \mathrm{l}^{-1}\left(50 \% \mathrm{O}_{2}\right.$-saturation), decreasing to $2.9 \mathrm{ml} \mathrm{l}^{-1}$ (43\% $\mathrm{O}_{2}$-saturation) in October. After this decrease in oxygen concentration the mean Hcy concentration in November was $1.1 \mathrm{mM}$ with individual measurements of $1.8 \mathrm{mM}$. With such high blood pigment concentrations the ventral sided of the abdomen was blue and the blood clotted immediately and became jelly-like when exposed to air. The oxygen concentrations in the bottom water varied between 4.5 $\mathrm{ml} \mathrm{l}^{-1}$ (67\% $\mathrm{O}_{2}$-saturation) and $6.7 \mathrm{ml} \mathrm{l}^{-1}\left(94 \% \mathrm{O}_{2}\right.$ saturation) in the period November 1987 to February 1988. Between November 1987 and January 1988 blood Hcy-concentrations did not decrease significantly ( $p>0.05$, KW test). Between January and February, however, a significant $(p<0.01$, U-test) decrease in Hcy took place.

After the spring plankton bloom in 1988 the oxygen concentration decreased and reached $3.1 \mathrm{ml} \mathrm{l}^{-1}$ (43\% $\mathrm{O}_{2}$-saturation) in June. In this spring period the Hcy concentrations of lobsters showed a peak in April, which was significantly ( $p<0.001$, U-tests) higher than both the March and May Hcy concentrations. By the beginning of August the oxygen concentration in the bottom water was down to $2.8 \mathrm{ml} \mathrm{l}^{-1}\left(38 \% \mathrm{O}_{2}\right.$-saturation). From June to September the Hcy synthesis in $N$. norvegicus resulted in a significant ( $\mathrm{p}<0.005$, U-test) increase in Hcy concentration, with a further significant ( $p<0.005$, U-test) increase in October. After low oxygen in the bottom water $\left(1.4 \mathrm{ml} \mathrm{l}^{-1}, 21 \% \mathrm{O}_{2}\right.$-saturation) in October 1988 a significant ( $p<0.005$, U-test) decrease in blood Hcy-concentrations was recorded between October and November. 
Table 2. Nephrops norvegicus. Percentage occurrence of food items in the stomachs of lobsters from 31 trawl samples in SE Kattegat from 1986 to 1988 , and from 4 trawl samples in NE Kattegat in October 1988. Number of stomachs analysed and stomach weight/body weight ratio (\%) are given for each sampling occasion

\begin{tabular}{|c|c|c|c|c|c|c|c|c|c|}
\hline \multirow[t]{3}{*}{ Food items } & \multicolumn{8}{|c|}{ SE Kattegat } & \multirow{3}{*}{$\begin{array}{c}\text { NE Kattegat } \\
\text { Oct } \\
1988\end{array}$} \\
\hline & Oct & Sep & Oct & Nov & Dec & Apr & Sep & Average & \\
\hline & 1986 & 1987 & 1987 & 1987 & 1987 & 1988 & 1988 & $\begin{array}{l}\text { Oct } 1986 \text { to } \\
\text { Apr } 1988\end{array}$ & \\
\hline Crustaceans & 68.3 & 43.5 & 65.7 & 66.4 & 66.7 & 83.1 & 11.8 & 65.6 & 90.0 \\
\hline Crustaceans unident. & 30.2 & 15.7 & 15.7 & 51.1 & 66.7 & 51.0 & 11.0 & 38.4 & 84.3 \\
\hline Cumacea & 2.7 & & 3.5 & & & & & 1.0 & 4.6 \\
\hline Diastylis rathkei & 1.5 & 34.9 & 4.9 & 7.8 & & 6.4 & & 9.3 & 2.1 \\
\hline Gammeridae & & & 0.7 & & & & & 0.1 & \\
\hline Leuconid sp. & 3.0 & & 1.2 & 1.6 & & 21.2 & & 4.5 & \\
\hline Nephrops norvegicus & 17.3 & & 17.0 & & & 2.5 & & 6.1 & 4.3 \\
\hline Nephrops egg & & & 0.7 & & & & 2.5 & 0.1 & \\
\hline Ostracoda & 16.7 & & 7.2 & 9.0 & & 29.4 & 0.8 & 10.4 & \\
\hline Pagurus bernhardus & 2.7 & & 28.3 & 6.7 & & 18.8 & & 9.4 & 1.3 \\
\hline philomedes globosus & & & 1.2 & & & & & 0.2 & \\
\hline Echinoderms & 29.3 & 39.1 & 33.0 & 56.5 & 33.3 & 82.0 & 24.3 & 45.5 & 42.6 \\
\hline Amphiura/Ophiura & 23.2 & 8.6 & 13.6 & 47.9 & 33.3 & 61.7 & & 31.4 & 39.2 \\
\hline Amphiura spp. & 4.6 & 24.2 & 11.9 & 6.2 & & 14.1 & & 10.2 & \\
\hline Brissopsis lyrifera & 4.6 & 13.5 & 9.9 & 4.8 & & 12.7 & 23.6 & 7.6 & 15.8 \\
\hline Ophiura spp. & & & 2.1 & & & 6.1 & 0.6 & 1.4 & \\
\hline Molluscs & 34.3 & 41.3 & 43.9 & 78.1 & 33.3 & 82.1 & 2.9 & 52.2 & 59.4 \\
\hline Abra spp. & 1.5 & 13.5 & 14.7 & 61.1 & 33.3 & 70.8 & 0.8 & 32.5 & 53.9 \\
\hline Arctica islandica & & & & 3.4 & & 7.9 & & 1.9 & 2.6 \\
\hline Cardium echinatum & 13.2 & & 7.9 & 22.3 & 33.3 & 18.4 & 0.8 & 15.8 & 7.4 \\
\hline Corbula gibba & & & & 1.2 & & & & 0.2 & 4.2 \\
\hline Molluscs unident. & 22.3 & 38.5 & 23.6 & 4.2 & 33.3 & & & 20.3 & \\
\hline Mytilus edulis & & & & 0.6 & & 5.5 & & 1.0 & 1.3 \\
\hline Nucula spp. & & 11.2 & 7.4 & 39.5 & 11.1 & 28.1 & 1.3 & 16.2 & 4.3 \\
\hline Onoba vitrea & 1.5 & & & 0.6 & & & & 0.4 & \\
\hline Philine scabra & & & & & & & & 0.0 & 1.3 \\
\hline Rissoa violacea & & & & 0.6 & & & & 0.1 & \\
\hline Turritella spp. & & & & 1.5 & & 6.9 & & 1.4 & 1.5 \\
\hline Polychaetes & 41.2 & 60.2 & 48.5 & 44.5 & 66.7 & 72.3 & 1.3 & 55.5 & 55.2 \\
\hline Ampharetidae & & & 1.0 & & & & & 0.2 & \\
\hline Aphrodite aculeata & 1.5 & 8.3 & 0.8 & 3.7 & & & & 2.4 & \\
\hline Glycera alba & 4.2 & 3.6 & 1.8 & 9.5 & 33.3 & 9.7 & & 10.3 & 10.9 \\
\hline Glycera spp. & 5.7 & 5.0 & 16.3 & 16.7 & & 19.9 & 1.3 & 10.6 & 10.4 \\
\hline Lumbrineris fragilis & & & 1.0 & 1.2 & & & & 0.4 & \\
\hline Maldane sarsi & & & 2.1 & & & 1.8 & & 0.7 & \\
\hline Myriochele oculata & & 10.7 & 9.5 & & & & & 3.4 & \\
\hline Nereis spp. & & & 4.2 & & & & & 0.7 & \\
\hline Pectinaria spp. & 3.0 & 19.9 & 11.8 & 11.1 & 33.3 & 24.0 & & 17.2 & 26.5 \\
\hline Polychaetes unident. & 28.3 & 30.6 & 25.5 & 10.7 & & 40.3 & & 22.6 & 18.3 \\
\hline Rhodine spp. & & & & 0.6 & & & & 0.1 & \\
\hline Terebellidae & & & 1.0 & & & & & 0.2 & \\
\hline Pisces & 6.8 & 0.0 & 9.7 & 5.8 & 0.0 & 4.0 & 0.8 & 4.4 & 11.9 \\
\hline Plant material & 1.5 & 0.0 & 0.7 & 0.0 & 0.0 & 0.0 & 2.5 & 0.4 & 0.0 \\
\hline No. stomachs & 52 & 19 & 112 & 127 & 9 & 45 & 107 & & 77 \\
\hline Stomach wt/body wt $(\%)$ & 1.2 & 1.0 & 1.0 & 0.8 & 1.1 & 1.2 & 0.1 & & 1.1 \\
\hline
\end{tabular}

In 1987 and 1988 blood pigment analyses of Nephrops norvegicus were carried out at Stn 13 (65 m depth; Fig. 1). The mean concentrations were $<0.4 \mathrm{mM} \mathrm{Hcy}$ in the 1987 samples, but significantly $(p<0.01, U$-test $)$ lower (about $0.15 \mathrm{mM} \mathrm{Hcy}$ ) in the 1988 samples (Table 3).

\section{Scotland}

Blood samples of Nephrops norvegicus from the Moray Firth on the Scottish east coast in January 1987 (Hagerman \& Baden 1988) showed a 'normal' mean Hcy concentration of $0.66 \mathrm{mM}(\mathrm{SD}=0.15 \mathrm{mM}, \mathrm{n}=11)$ 


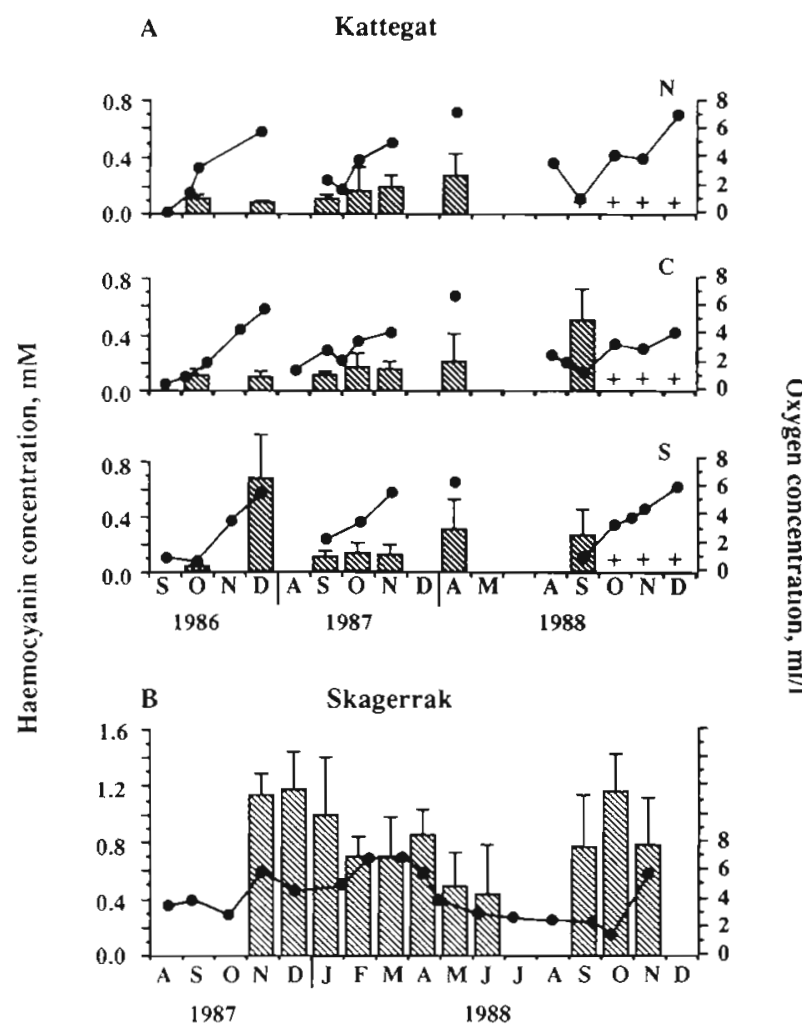

Fig. 6. Nephrops norvegicus. Mean concentration (mM) and standard deviation of blood haemocyanin (bars), in relation to the actual oxygen concentration (lines; $\mathrm{ml} \mathrm{l}^{-1}$ ) at each sampling occasion. (A) Sampling in the northern (N), central (C) and southern (S) subareas in the SE Kattegat (Fig. 1) between 1986 and 1988. (B) Sampling in the Skagerrak 1987 and 1988 (Stn 9, Fig. 1). Samples with only dead lobsters indicated by $(+)$

similar to lobsters from Loch Torridon on the Scottish west coast (30 $\mathrm{m}$ depth) in September 1988 (0.69 mM, $\mathrm{SD}=0.34 \mathrm{mM}, \mathrm{n}=19)$. Males in the Loch Torridon population had a significantly ( $\mathrm{p}<0.02$, U-test) higher level of blood pigment than females with some male specimens exceeding $1.2 \mathrm{mM}$. This sex-related difference in haemocyanin was never found in any samples from the Kattegat or the Skagerrak.

\section{Reports from fishermen}

During autumn 1987 Nephrops norvegicus were reported in gill-nets at $8 \mathrm{~m}$ depth and even in eel pots at $2 \mathrm{~m}$ depth near Stn 10 in the Skagerrak. N. norvegicus are usually restricted to depths below 25 to $30 \mathrm{~m}$. Blood samples were taken from $N$. norvegicus ( $\mathrm{n}=52$ ) caught at Stns 10,11 and 12 (Fig. 1) in October and November 1987. Hcy concentrations were low $(<0.2 \mathrm{mM}$ ) in all individuals (Table 3). At Stn $10 \mathrm{Hcy}$ concentrations were just above $0.7 \mathrm{mM}$ in March and April and thus within the 'normal' range. In the northern part of the Kattegat (Stn 3) fishermen reported dead and dying lobsters in creels in October 1987. During November 1987 mean Hcy concentration in lobsters still alive in this area was $0.16 \mathrm{mM}$. In the autumn 1988 $N$. norvegicus were caught in pelagic herring trawls in the Kattegat, and in the Skagerrak (Stn 8) N. norvegicus were caught in unusually high densities in anchor-seine nets. The mean Hcy concentration of $N$. norvegicus in this catch was also low $(0.15 \mathrm{mM})$.

\section{Discoloured gills}

Dark or black gills of live Nephrops norvegicus were observed from all stations in the Kattegat and from Stns 3,7 and 10 in the Skagerrak. The percentage of coloured gills in the Kattegat area varied between 10 and $20 \%(n=254)$ for both sexes, but $73 \%(n=22)$ of females caught in the subarea $\mathrm{S}$ in September $1988 \mathrm{had}$ dark gills. During autumn 1988 some $N$. norvegicus that had black gills also had about $10 \mathrm{~mm}$ diameter corroded holes in the carapax (Stns 3 and 7). The dark and black layer observed on the gills from $N$. norvegicus in the Kattegat, according to Dando \& Notte (unpubl.), is a deposition of mineral particles of oxidized manganese. These were imbedded in the mucus of the gills under hypoxic conditions. The manganese layer did not seem to disappear in normoxia as the frequency of coloured gills in the spring was about the same as in the previous autumn.

\section{Haemocyanin concentrations: experiments}

\section{Changes related to food}

The influence of starvation on Hcy metabolism in Nephrops norvegicus resulted in an average decrease in Hcy concentration of 0.6 to $0.8 \% \mathrm{~d}^{-1}$, corresponding to a $50 \%$ reduction within 66 to $89 \mathrm{~d}$ (Table $4 \mathrm{~A}$ ).

In the feeding experiments Nephrops norvegicus consumed almost equal amounts of shrimps, Pandalus borealis and brittle stars Amphiura/Ophiura spp., about 7 to $9 \mathrm{~g} \mathrm{~d}^{-1}$ per $\mathrm{kg}$ body weight (Table 4B). The influence of different food types on the Hcy concentration showed that when feeding entirely on brittle stars, the blood Hcy level decreased in all individuals, whereas when feeding on crustaceans the blood Hcy increased in $50 \%$ of the individuals and decreased in the remaining $50 \%$. The rate of change in Hcy concentration had a wide variation.

\section{Changes related to oxygen concentration}

Nephrops norvegicus exposed to severe hypoxia $1<20 \% \mathrm{O}_{2}$ saturation) showed, after a period of exposure, a sudden and rapid decrease in blood Hcy con- 
Table 3. Nephrops norvegicus. Blood haemocyanin concentrations (mean, SD) of lobsters from different stations (see Fig. 1) in the coastal NE Kattegat and the Skagerrak. a: numbers sampled from each station

\begin{tabular}{|llcccc|}
\hline Stn & Date & $\mathrm{n}$ & $\begin{array}{c}\text { Depth } \\
\text { (m) }\end{array}$ & $\begin{array}{c}\text { Mean Hcy } \\
\text { (mM) }\end{array}$ & SD \\
\hline 1 & 17 Dec 1987 & 20 & 36 & 0.42 & 0.14 \\
2 & 17 Dec 1987 & 20 & 50 & 0.30 & 0.21 \\
3 & 4 Nov 1987 & 13 & 35 & 0.35 & 0.29 \\
4 & 4 Nov 1987 & 12 & 36 & 0.16 & 0.17 \\
5 & 14 Sep 1987 & 18 & 45 & 0.14 & 0.08 \\
6 & 14 Sep 1987 & 13 & 40 & 0.09 & 0.04 \\
7 & 24 Oct 1988 & 6 & 45 & 0.21 & 0.08 \\
8 & 5 Oct 1988 & 13 & 33 & 0.15 & 0.04 \\
9 & 1987/88 & See Fig. $6 \mathrm{~B}$ & 42 & & \\
10 & 22 Nov 1987 & 20 & 39 & 0.20 & 0.08 \\
10 & 10 Mar 1988 & 20 & 39 & 0.71 & 0.30 \\
10 & 22 Apr 1988 & 20 & 39 & 0.76 & 0.24 \\
11 & 22 Oct 1987 & 19 & 55 & 0.13 & 0.07 \\
12 & 27 Oct 1987 & 13 & 60 & 0.17 & 0.06 \\
13 & 7 Jan 1987 & 12 & 42 & 0.32 & 0.21 \\
13 & 10 Nov 1987 & 18 & 42 & 0.37 & 0.24 \\
13 & 3 May 1987 & 19 & 42 & 0.16 & 0.13 \\
13 & 31 Oct 1988 & 20 & 42 & 0.14 & 0.04 \\
\hline
\end{tabular}

centration. The length of time before the decline began depended on the oxygen concentration (Fig. 7). When exposed to $10 \% \mathrm{O}_{2}$-saturation an immediate reduction of the mean Hcy concentration by $65 \%$ of the initial value occurred within $4 \mathrm{~d}$. After $4 \mathrm{~d}$ mortality was $90 \%$ in a sample size of 10 . The lobsters in $12 \%(\mathrm{n}=8)$ and $15 \%(\mathrm{n}=8) \mathrm{O}_{2}$ saturation first increased their Hcy concentrations, relative to the 4 series of control lobsters in fully saturated water $(n=38)$, to a threshold $(12 \%: 15 \mathrm{~d}, 15 \%$ : $36 \mathrm{~d})$. After that a decrease in Hcy level occurred at a rate similar to that recorded for lobsters in $10 \% \mathrm{O}_{2}$ saturation, and the percentage mortality after $4 \mathrm{~d}$ was high $\left(100 \%\right.$ for $12 \% \mathrm{O}_{2}, 40 \%$ for $15 \% \mathrm{O}_{2}$ ). Lobsters exposed to $20 \% \mathrm{O}_{2}$ saturation

\begin{tabular}{ccccc|}
\hline A & $\begin{array}{c}\text { Temp. } \\
\text { range }\end{array}$ & Days & n & $\begin{array}{c}\text { Mean \% red. } \\
\mathrm{d}^{-1}(\mathrm{SD})\end{array}$ \\
\hline Expt 1 & $7-9.5^{\circ} \mathrm{C}$ & 40 & 6 & $0.76(0.15)$ \\
Expt 2 & $4-6{ }^{\circ} \mathrm{C}$ & 81 & 7 & $0.57(0.07)$ \\
\hline
\end{tabular}

were transferred to $15 \% \mathrm{O}_{2}$ saturation (Fig. 7) after $3 \mathrm{wk}$ of exposure. This treatment resulted in a relatively rapid decrease of $58 \%$ Hcy within a further $13 \mathrm{~d}$. The decrease in Hcy concentration of $30 \%$ within $33 \mathrm{~d}$ $\left(0.9 \% \mathrm{~d}^{-1}\right)$ for the control groups is in accordance with the decrease for starving lobsters in this temperature range, as described above (Table $4 \mathrm{~A}$ ).

\section{Behavioural observations}

When exposing Nephrops norvegicus to $20 \% \mathrm{O}_{2}$ saturation some of the lobsters stood high above the substrate with legs flexed ('tiptoeing') but were still eating when offered food at the beginning of the experiment. After 3 wk the lobsters stopped feeding. $N$. norvegicus exposed to $<15 \% \mathrm{O}_{2}$-saturation showed no sign of feeding. When exposed to $12 \% \mathrm{O}_{2}$-saturation all lobsters were tiptoeing and supported the elevation of the body from the substrate with the claws and telson. The Iobsters remained elevated until they became moribund and sluggish, barely moving when touched. This stage lasted for 2 to $3 \mathrm{~d}$ after which they died.

\section{DISCUSSION}

\section{Biomass and population structure}

The emergent behaviour of Nephrops norvegicus in relation to their burrows in the sediment is known to vary due to factors such as temperature, salinity, oxygen, light, depth, sediment structure and reproductive status (Simpson 1965, Thomas \& Figueiredo 1965, Bagge \& Munch-Petersen 1979, Chapman 1980), and the catchability of the lobsters during trawling may well be partly dependent on these factors. As a consequence, trawling will not, in most cases, give a quan-

Table 4. Nephrops norvegicus. A: Mean percentage reduction of blood haemocyanin concentration in lobsters starved for 40 (Expt 1) and 81 (Expt 2) days. B: Consumption ( $\mathrm{g} \mathrm{d}^{-1}$ per $\mathrm{kg} N$. norvegicus [wet wt]), when entirely fed with (i) crustaceans or (ii) echinoderms, and the number of $N$. norvegicus (n) having a decrease or increase in haemocyanin in relation to the different food items. The lobsters were fed for 40 (Expt 1) and 81 (Expt 2) days. The experiments were conducted under normoxic conditions

\begin{tabular}{|c|c|c|c|c|c|c|c|}
\hline B & Temp. range & Days & $\mathrm{n}$ & Type of food & $\begin{array}{l}\text { Consumption } \\
\left(\mathrm{g} \mathrm{d}^{-1} \mathrm{~kg}^{-1}\right)\end{array}$ & $\begin{array}{c}n \\
\text { Hcy decreased }\end{array}$ & $\begin{array}{c}n \\
\text { Hcy increased }\end{array}$ \\
\hline Expt 1 & $7-9.5^{\circ} \mathrm{C}$ & 40 & $\begin{array}{l}6 \\
6\end{array}$ & $\begin{array}{l}\text { Crustaceans } \\
\text { Echinoderms }\end{array}$ & $\begin{array}{l}7.21 \\
9.40\end{array}$ & $\begin{array}{l}3 \\
6\end{array}$ & $\begin{array}{l}3 \\
0\end{array}$ \\
\hline Expt 2 & $4-6{ }^{\circ} \mathrm{C}$ & 81 & $\begin{array}{l}4 \\
5\end{array}$ & $\begin{array}{l}\text { Crustaceans } \\
\text { Echinoderms }\end{array}$ & $\begin{array}{l}9.92 \\
9.32\end{array}$ & $\begin{array}{l}2 \\
5\end{array}$ & $\begin{array}{l}2 \\
0\end{array}$ \\
\hline
\end{tabular}




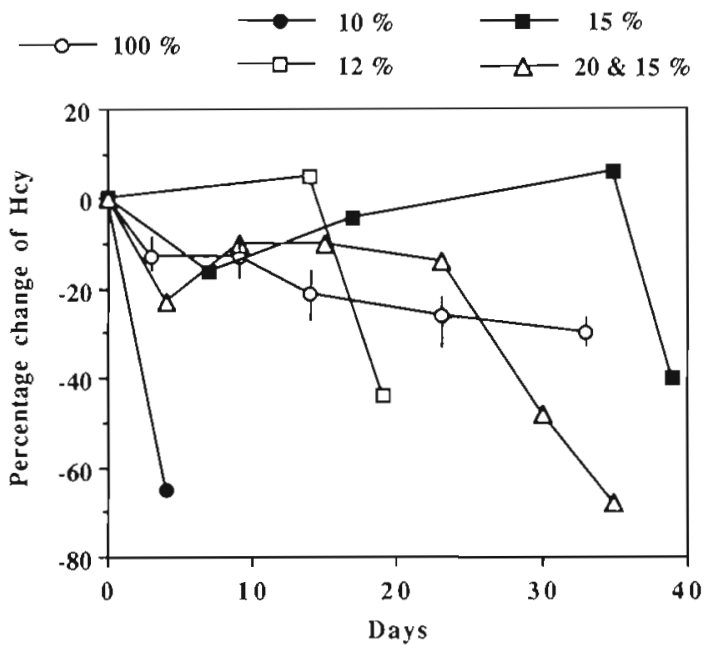

Fig. 7. Nephrops norvegicus. Percentage change in haemocyanin concentration of lobsters exposed to different oxygen concentrations. Results for $100 \% \mathrm{O}_{2}$-saturation are shown as the median (o), minimum, and maximum (vertical bars) of 4 series of experiments. $N$. norvegicus in the ' $20 \& 15 \%$ ' series were exposed to $20 \% \mathrm{O}_{2}$-saturation for $3 \mathrm{wk}$ and thereafter to $15 \% \mathrm{O}_{2}$-saturation

titative estimate of the abundance of the $N$. norvegicus population in an area. In order to reduce the variation of some of these factors between the samplings, trawling in this study was carried out at fixed stations during daytime so that depth and sediment structure would be relatively constant and spatial variations in salinity, light and temperature would be relatively small. Temperature during autumn sampling was never $<5^{\circ} \mathrm{C}$, which is the temperature at which $N$. norvegicus are believed to become inactive (Jensen 1965). In spring the water temperature was about $5^{\circ} \mathrm{C}$ which could have reduced the activity and thereby the catchability of the lobsters. Oxygen concentration in the bottom water and the reproductive status of the females were probably the main factors affecting the catchability of $N$. norvegicus at least during autumn.

Since 1980 low oxygen concentrations have been recorded in the bottom water of the SE Kattegat during autumn of each year. Levels of oxygen concentration and duration of the oxygen depletion varied between years, mainly due to variations in nutrient load, intensity in phytoplankton blooms and hydrographical factors. However, during the 1980's a general decrease in oxygen concentrations and an increase in duration of time with low oxygen have been observed. In the autumn of 1985, 1986 and 1988 low ( $<1 \mathrm{ml} \mathrm{l}^{-1}$ ) oxygen concentrations were recorded in the bottom water for 2 to $4 \mathrm{wk}$, and during these periods dead lobsters were caught (Petersen \& Petersen 1986, this study). Catches of Nephrops norvegicus from ICES area 4257 show that catch per unit effort increased during the early 1980 's and then decreased (Fig. 5). Furthermore, a high yearto-year variation in commercial catches was found in this area, compared to the NE Kattegat (ICES area 4356). The southern part of Kattegat has been severely exposed to low oxygen concentration during the 1980 's, whereas in the northern part the exposure has been moderate. Low oxygen concentrations force lobsters to emerge from their burrows resulting in an increased catchability (Bagge \& Munch-Petersen 1979, Baden et al. 1984). Variation in hypoxia between years will therefore cause a variation in the catch of the lobsters and this might explain the different patterns in CPUE between the 2 areas.

The biomass (CPUE) of Nephrops norvegicus showed a general decrease in the study area during the investigated period and during the last 5 samplings no lobsters were caught (Fig. 3). Increased exploitation caused by moderate hypoxia and finally severe hypoxia were most probably responsible for the decline in biomass. The discrepancies between CPUE in Figs. 3 and 5 are because area 4257 covers not only most of the study area, from which the CPUE in Fig. 3 derives, but also areas less affected by hypoxic conditions, west of the study area. When catches decrease in the study area the fishermen can go to other areas within 4257 .

The size distribution of the Nephrops norvegicus population was similar throughout the period investigated, and males were dominant (mean $=78 \%$ of total) on most sampling occasions. These results are in agreement with what has been found in other areas where males were found to dominate in the catches without any seasonal variation in size frequency distribution (Thomas \& Figueiredo 1965). Females stay mainly in the burrows during the egg-carrying period (September to May), as do the juvenile lobsters. During low oxygen tensions, however, changes of the population structure of $N$. norvegicus in trawl catches can occur, as females leave the burrows (Bagge \& MunchPetersen 1979). In this investigation berried females dominated in the catch in September 1988 when oxygen concentrations $<1 \mathrm{ml} \mathrm{l^{-1 }}$ were recorded in the bottom water.

\section{Diet}

The mean percentage occurrence of Crustacea, Polychaeta, Echinodermata and Mollusca in the stomachs of Nephrops norvegicus in SE Kattegat was fairly similar, between 46 and $66 \%$ (Table 2). This suggests that they are not feeding selectively. It has also been stated in other reports that $N$. norvegicus seems to be a varied feeder, taking available organisms indiscriminately (Thomas \& Davidson 1962, Oakley 1979, Bailey et al. 1986). No detailed comparison has, however, been made between food intake by $N$. nor- 
vegicus and the benthic invertebrates in the same area. For the Kattegat, quantitative data on benthic invertebrates are available from several stations in the trawled areas and over the same period (1986 to 1988) (Rosenberg \& Loo 1988, Rosenberg unpubl.). Unfortunately, only a qualitative comparison can be made as the food ingested by $N$. norvegicus was well masticated and difficult to identify.

Benthic data from 6 stations in the vicinity of the northern subarea, 7 in the center and 3 in the southern subarea were selected for a cursory comparison (depth range 24 to $57 \mathrm{~m}$ ). Dominant organisms in terms of abundance and biomass in the northern and middle subareas were Amphiura filiformis (O. F. Müller) and A. chiajei (Forbes); other numerically dominant organisms were Maldane sarsi (Malmgren), Myriochele oculata (Zaks), Philomedes globosus (Lilljeborg), and in terms of biomass, Brissopsis lyrifera. In the southern subarea $P$. globosus, Heteromastus filiformis (Cleparede) and $M$. sarsi were dominant in abundance, and Arctica islandica (L.), A. filiformis and B. lyrifera were dominant in terms of biomass.

Most of these macrobenthic species were also frequently found in Nephrops norvegicus stomachs (Table 2), indicating that $N$. norvegicus tend to ingest what is readily available. Abra spp. were frequently recorded in the stomachs, but not among the benthic dominants. Both Abra alba (W Wood) and A. nitida (Müller) can, temporarily, be locally abundant in the Kattegat (Rosenberg \& Loo 1988). The highest occurrence in the stomachs was recorded for brittle stars (amphiuroids and ophiuroids). In the other studies cited above brittle stars were found less frequently, except in the Minch, off the Scottish west coast, where they formed 18 to $51 \%$ of the diet (Thomas \& Davidson 1962). The high occurrence in the Kattegat was probably due to the dominance of brittle stars in this area, and it is not known how common this animal group was in other regions.

Feeding experiments in this investigation showed an average food intake of about $9 \mathrm{~g} \mathrm{~d}^{-1}$ per $\mathrm{kg}$ Nephrops norvegicus (wet wt). According to Chapman (1980) and Smith (1988) the density of $N$. norvegicus is around $0.15 \mathrm{~m}^{-2}$ in most areas but can vary from 0.1 to $3.8 \mathrm{~m}^{-2}$ when estimated by underwater photography and by diving. The average total length of $N$. norvegicus in our samples from the $\mathrm{SE}$ Kattegat was around $14 \mathrm{~cm}$ (43 mm, carapace length) (Fig. 4) corresponding to a mean weight of $52 \mathrm{~g}$ (wet wt). If the $N$. norvegicus population is eliminated through low oxygen concentrations the result could be a reduction in predation pressure of ca $25 \mathrm{~g}$ (wet wt) benthic infauna $\mathrm{m}^{-2} \mathrm{yr}^{-1}$, assuming an initial $N$. norvegicus density of $0.15 \mathrm{~m}^{-2}$. In addition to this, during the autumn with hypoxic conditions in the SE Kattegat, about 80 to $90 \%$ of the demersal fish fauna had disappeared (Pihl 1989) with a probable but still unknown decrease in the predation pressure on the infauna (Pihl unpubl.). Thus, apart from the likely direct effect of hypoxia, a considerable decrease in predation pressure might be an important influence for determining the community structure of the benthic infauna

\section{Haemocyanin concentrations}

Moderate hypoxia

Stress from hypoxia induces several parallel physiological changes to compensate for the effect of low $\mathrm{O}_{2}$-saturation. In many crustaceans one way of compensating is to increase the capacity of $\mathrm{O}_{2}$-uptake by increasing the blood Hcy concentration. In laboratory experiments moderate hypoxia of 20 to $40 \% \mathrm{O}_{2}$ saturation induced an increase in synthesis of Hcy in American lobster Homarus americanus (Milne Edwards) (Senkbiel \& Wriston 1981), isopod Mesidotea entomon (L.) (Hagerman \& Oksama 1985), Nephrops norvegicus (Hagerman \& Uglow 1985) and shrimp Crangon crangon (L.) (Hagerman 1986). In these investigations the rates of Hcy synthesis were found to be 6 to $9 \%$ of the initial value per day, provided enough food was available. Field results from the Skagerrak (Stn 9) suggest that $N$. norvegicus synthesized Hcy in moderate hypoxia (38 to $43 \%$ saturation). The $\mathrm{O}_{2}$ concentration experienced by the lobster in the burrow was probably even lower than on the bottom (Atkinson \& Taylor 1988, Rosenberg \& Loo 1988). The rate of Hcy synthesis in the Skagerrak cannot be estimated as the intervals between samples were too long. The maximum Hcy concentration of $1.8 \mathrm{mM}$ recorded in $N$. norvegicus during moderate hypoxia was also found for $C$. crangon by Hagerman (1986).

During normoxia (January to June) a slow decrease to 'normal' blood Hcy concentrations occurred, while a faster decrease took place between October and November due to the onset of less than $20 \% \mathrm{O}_{2}$ saturation in the bottom water. It seems that lobsters having raised their Hcy concentration during moderate hypoxia can keep this level for some time even after the return of normoxia.

\section{Severe hypoxia}

In severe hypoxia ( $<20 \% \mathrm{O}_{2}$-saturation) Nephrops norvegicus in our experiments became less active and raised the body by extending their legs, a behaviour also found previously (Batterton \& Cameron 1978, Senkbiel \& Wriston 1981, Hagerman \& Uglow 1985). The experiments also showed that even when exposed 
to severe hypoxia, down to $12 \% \mathrm{O}_{2}$-saturation, the lobsters initially tried to compensate for the low oxygen concentration by increasing the Hcy concentration of the blood compared to controls. In this way $N$. norvegicus survived about $4 \mathrm{wk}$ in $15 \% \mathrm{O}_{2}$-saturation and about $2 \mathrm{wk}$ in $12 \% \mathrm{O}_{2}$-saturation. Before starting to increase a slight decrease in the Hcy concentration occurred after 3 and 4 d for lobsters in 15 and $20 \%$ but not in $12 \% \mathrm{O}_{2}$-saturation. This is probably due to an initial increase of the haemocyanin $\mathrm{O}_{2}$-affinity by raising the blood pH (Schmidt-Nielsen 1975). This compensation seemed to work for about a week, when exposing lobsters to 15 and $20 \% \mathrm{O}_{2}$-saturation, and the Hcy concentrations were the same as for lobsters in $100 \% \mathrm{O}_{2}$-saturation. However, to meet the stress from $12 \% \mathrm{O}_{2}$-saturation and prolonged exposure to 15 and $20 \%$, the lobsters increased their Hcy concentration compared to lobsters in $100 \% \mathrm{O}_{2}$-saturation. The catabolism of haemocyanin during the hypoxic experiments was a rapid process lasting no longer than a week followed by mortality. In $10 \% \mathrm{O}_{2}$-saturation the lobsters were so stressed that no Hcy compensation to low oxygen levels occurred, and the lobsters survived for only 2 to $4 \mathrm{~d}$. A rapid decrease in Hcy and high mortality was also found in $10 \% \mathrm{O}_{2}$-saturation in a similar experiment on $N$. norvegicus by Hagerman et al. (1990).

Field data on lobster Hcy concentrations during hypoxia where the Hcy concentration decreased to less than $10 \%$ of what is regarded as the normal value (Hagerman \& Baden 1988, this investigation) seem to be in accordance with our laboratory experiments. Thus, low haemocyanin concentrations found in Nephrops norvegicus in the SE Kattegat were most probably due to the low $\mathrm{O}_{2}$-saturations (less than $15 \%$ ) over a $4 \mathrm{wk}$ period.

In normoxia, catabolism of Hcy has been described as an effect of starvation, when the blood protein are used as an energy resource, for example in Carcinus maenas (L.) (Uglow 1969) and in Homarus gammarus (Hagerman 1983). Our experiments on the rate of catabolism when starving Nephrops norvegicus under normoxic conditions correlate well with these results in showing nearly a $1 \% \mathrm{~d}^{-1}$ decrement of the initial Hcy concentration.

The decrease of Norway lobster Hcy is unlikely to be explained by lack of food availability. As previously mentioned benthic infauna were abundantly available and during initial hypoxia perhaps even more accessible when both lobsters and some of the infauna emerged from the sediment (Dyer et al. 1983, Rosenberg \& Loo 1988). In our experiments we found that when $\mathrm{O}_{2}$-saturation was below $15 \%$ the lobsters stopped feeding and this was also the case in the field in September 1988, when all the lobsters had empty stomachs. Thus, in low oxygen concentrations, the lobsters suffer from hypoxia-induced starvation rather than direct lack of food.

The results from field samples of low Hcy concentrations in Nephrops norvegicus from the Skagerrak indicate that severe oxygen depletion may occur even in some of the deeper coastal areas (Table 3 ).

\section{Recovery}

The recovery of blood pigment concentration to 'normal' concentrations was very slow after the return of normoxia in the bottom water. The only exception was from subarea $S$ in autumn 1986, the first year when the effect of hypoxia on the lobsters was examined (Hagerman \& Baden 1988). As indicated by our feeding experiments, where only lobsters fed on crustaceans increased their blood Hcy, and by Castell \& Budson (1974), Hagerman (1983) and Depledge \& Bjerregård (1989), other crustaceans are an important part of the diet for crustaceans, supplying essential proteins, certain vitamins and copper for haemocyanin synthesis. The content of crustaceans in the diet of Norway lobsters in the southern Kattegat was only about $20 \%$ less than in the diet from areas in the northern Kattegat. According to Depledge (1989) a translocation of part of the copper, mainly from haemocyanin to the hepatopancreas, occurs in crustaceans when starved and more than $50 \%$ of the copper may be excreted. Hypoxic conditions force not only the lobsters but also their food items into severe starvation. Under this condition more than $50 \%$ leakage of copper could be possible. As food and not seawater is the most important source of copper to crustaceans (Windom \& Smith 1979, Bryan 1984, Depledge \& Bjerregård 1989) the slow recovery of $\mathrm{Hcy}$ could more likely be due to copper deficiency than to the $20 \%$ lower abundance of crustaceans in the diet in the SE Kattegat compared to the NE Kattegat. How the layer of manganese on the gills might affect oxygen uptake in the 'black gill' individuals remains to be investigated. It is also possible that some elevation of the Hcy concentration took place during early summer, but the concentration may have decreased again due to low oxygen prior to the first sampling in September

\section{Haemocyanin concentration as a biomarker}

In a review of physiological biomarkers, Mayer et al. (1990) conclude that it is important to develop 'in situ' biomarkers of ecological relevance.

The repeated occurrence of low blood Hcy levels in different localities in the Kattegat and the Skagerrak 
confirms that blood pigment concentration can be a useful in situ biomarker of the degree of hypoxia to which the lobsters have been exposed. Our experiments show that catabolism of Hcy is one of the last energy resources used after exposure to serious hypoxia for some weeks. Glycogen is generally an important energy store, being mobilized to fuel more rapidly than fat. Under hypoxia glycogen can yield energy by breakdown to lactic acid (Schmidt-Nielsen 1975). Decrease of glycogen in the hepatopancreas of Carcinus maenas was found when the crabs were stressed by benzene and dimethylnaphthalene (Mantel et al. 1985). Thus glycogen content of the hepatopancreas in sedentary crustaceans might provide another biomarker of stressed environments worthy of investigation.

\section{CONCLUSIONS}

During the 1980's the SE Kattegat has suffered from severe and intensifying hypoxia which has been shown to affect benthic infauna (Rosenberg \& Loo 1988) and demersal fish (Pihl 1986, 1989). In this study we have found that Nephrops norvegicus, due to its relatively sedentary life, is one of the most severely affected species.

Both ecological and physiological disturbance of Nephrops norvegicus has been shown to occur during hypoxia. In a $3000 \mathrm{~km}^{2}$ area in the SE Kattegat these disturbances have been fatal, with no lobsters being caught at the sampling sites in the 12 mo since September 1988. During hypoxia a series of events make the lobsters unable to cope with the stressed environment. During moderate hypoxia lobsters emerge from the sediment, and are thereby overfished by trawlers. At even lower oxygen concentrations the lobsters are immobilized and unable to feed. Some lobsters had a black layer of mineralized manganese on the gills, and this layer did not disappear with return to normoxia. The layer might reduce oxygen uptake efficiency. At a later stage catabolism of the blood pigment protein haemocyanin helps the lobster to survive for a short period before death.

In the event of a much needed reduction of excessive nutrients levels, the underlying cause of hypoxia in the Kattegat, what are the chances of recovery of the Nephrops norvegicus stock in the area? As long as the hypoxia does not affect the NE Kattegat to the same degree as the southern part, the lobsters will most probably return, but after how long? The recruitment of $N$. norvegicus is not well documented. Juveniles are mainly found in small tunnels connected to the burrows of adult lobsters (Chapman 1980), but have also been observed to make their own burrows (Crnkovic 1968).
The highest survival potential may occur when juveniles are living in association with adults, perhaps by benefitting from food caught by adults. If this is the case, recovery would occur mainly by immigration from surrounding areas and this would be a very slow process, since migrations of adult Norway lobster are limited (Jensen 1965, Chapman 1980). If recovery can also occur by larval settlement, it could be faster. $N$. norvegicus reaches catchable size in about 4 to $6 \mathrm{yr}$, thus recovery of the population within a decade would be possible, provided all other factors such as food availability and sedimentary conditions are maintained.

Acknowledgements. We sincerely thank Mrs S. Havenhand, Mrs B. Hellman, Mr M. Ulmestrand and all personnel on the RV 'Argos' for valuable assistance during sampling, experiments and analysing of the data. We are very grateful to Drs C. Chapman, L. Hagerman and T. Pearson for their critical review of the manuscript and to Drs P. Dando and J. Notte who analysed the 'black gills' of Nephrops norvegicus from the Kattegat. Dr C. Chapman kindly helped us in obtaining blood samples from Scottish N. norvegicus. Financial support was provided by the Swedish Environmental Protection Board.

\section{LITERATURE CITED}

Antonini, E., Brunori, M. (1974). Transport of oxygen; respiratory protein. In: Hayaishi, O. (ed.) Molecular oxygen in biology: topics in molecular oxygen research. NorthHolland, Amsterdam, p. 219-274

Atkinson, R. J. A., Taylor, A. C. (1988). Physiological ecology of burrowing decapods. Symp. zool. Soc. Lond. 59: 201-226

Baden, S., Rosenberg, R., Hagerman, L., Bagge, O. (1984) Why does the catch of Norway lobster decrease in the Kattegat? Yrkesfiskaren 15/16: 16-17 (Swedish)

Baden, S., Loo, L.-O., Pihl, L., Rosenberg, R. (1990). Effects of eutrophication on benthic communities, including fish, Swedish west coast. Ambio 19 (3): 113-122

Bagge, O., Munch-Petersen, S. (1979). Some possible factors governing the catchability of Norway lobster in the Kattegat. Rapp. P.-v. Réun. Cons. perm. int. Explor. Mer 175 $143-146$

Bailey, N., Howard, F. G., Chapman, C. J. (1986). Clyde Nephrops: biology and fisheries. Proc. R. Soc. Edinb. 90B 501-518

Batterton, C. E., Cameron, J. N. (1978). Characteristics of resting ventilation and response to hypoxia, hypercapnia and emersion in the blue crab, Callinectes sapidus. J. exp. Zool. 203: 403-418

Bryan, G. W. (1984). Pollution due to heavy metals and their compounds. In: Kinne, O. (ed.) Marine ecology, Vol. V. Ocean management, Part 3. John Wiley, Chichester, p. $1289-1431$

Castell, J. D., Budson, S. D. (1974). Lobster nutrition: the effect on Homarus americanus of dietary protein levels. J. Fish. Res. Bd Can. 31: 1363-1370

Chapman, C. J. (1980). Ecology of juvenile and adult Nephrops. In: Cobb, J. S., Phillips, B. F. (eds.) The biology and management of lobsters, Vol. 2. Ecology and management. Academic Press, New York, p. 143-178 
Crnkovic, D. (1968). Some observations regarding the burrows of juvenile Nephrops norvegicus. Rapp. P.-v. Réun. Commn int. Explor. Scient. Mer Méditerr 19: 171-172

Depledge, M. H. (1989). Studies on copper and iron concentrations, distributions and uptake in the brachyuran Carcinus maenas (L.) following starvation. Ophelia 30 (3): 187-197

Depledge, M. H., Bjerregård, P. (1989). Haemolymph protein composition and copper levels in decapod crustaceans. Helgoländer Meeresunters. 43: 207-223

Dyer, M. F., Pope, J. G., Fry, P. D., Law, R. J., Portmann, J. E. (1983). Changes in fish and benthos catches off the Danish coast in September 1981. J. mar. biol. Ass. U.K. 63: $767-775$

Hagerman, L. (1983). Haemocyanin concentration in juvenile lobsters (Homarus gammarus) in relation to moulting cycle and feeding conditions. Mar. Biol. 77: 11-17

Hagerman, L. (1986). Haemocyanin concentration in the shrimp Crangon crangon (L.) after exposure to moderate hypoxia. Comp. Biochem. Physiol. 85A: 721-724

Hagerman, L., Baden, S. (1988). Nephrops norvegicus: field study of effects of oxygen deficiency on haemocyanin concentration. J. exp. mar. Biol. Ecol. 116: 135-142

Hagerman, L., Oksama, M. (1985). Haemocyanin concentration, carrying capacity and haemolymph $\mathrm{pH}$ under hypoxia in Mesidotea entomon. (L.) (Isopoda, Crustacea). Ophelia 24: 47-52

Hagerman, L., Sondergård, T., Weile, C., Hosie, D., Uglow, R. F. (1990). Aspects of blood physiology and ammonia excretion in Nephrops norvegicus under hypoxia. Comp. Biochem. Physiol. (in press)

Hagerman, L., Uglow, R. F. (1985). Effects of hypoxia on the respiratory and circulatory regulation of Nephrops norvegicus. Mar. Biol. 57: 273-278

Jensen, A. J. C. (1965). Nephrops in the Skagerrak and Kattegat (length, growth, tagging experiments and changes in stock and fishery yield). Rapp. P.-v. Réun. Cons. perm. int. Explor. Mer 156: 150-154

Mangum, C. (1983). Oxygen transport in the blood. In: Mantel, L. H. (ed.) The biology of Crustacea, Vol. 5. Internal anatomy and physiological regulation. Academic Press, New York, p. 373-429

Mantel, L. H., Flynn, E., Katz, M., Knapp, L. (1985). Effects of benzene and dimethylnaphthalene on homeostatic processes in two species of crabs. Mar. environ. Res. 17: 258-261

Mayer, F. L., Folmar, L. C., McCume, D. C., McKee, M. J., Rattner, B. A., Versteeg, D. J. (1990). Physiology/and nonspecific biomarkers. In: SETAC symposium. Present and future values to evaluate affects of toxical chemicals in ecosystems. Envir. Toxic. Chem. (in press)

Nickerson, K. W., van Holde, K. E. (1971). A comparison of molluscan and arthropod hemocyanin. I. Circular dichroism and absorption spectra. Comp. Biochem. Physiol. 39B: $855-872$

Oakley, S. J. (1979). Food, feeding behaviour and some aspects of the ecology of Nephrops norvegicus in the Irish sea. Ph.D. thesis, Univ. of Liverpool
Petersen, J. K., Petersen, G. I. (1986). Extension of oxygen deficiency in the southern Kattegat (based on interview with local fishermen). Report Marine Biological Laboratory, DK-3000 Helsingør, Denmark (Danish)

Pihl, L. (1986). Changes in the quality and composition of the fish fauna and its role in the ecosystem near the Laholm Bay. In: Rosenberg, R. (ed.) The eutrophication in Kattegat. Swedish Environmental Protection Board. Report No. 3272: 1-150 (Swedish)

Pihl, L. (1989). Effects of oxygen depletion on demersal fish in coastal areas of the south-east Kattegat. In: Ryland, J. S., Tyler, P. A. (eds.) Reproduction, genetics and distributions of marine organisms. Proc. 23th European Marine Biology Symp. p. 431-439. Olsen \& Olsen, Fredensborg, Denmark

Rosenberg, R. (1985). Eutrophication - the future marine coastal nuisance? Mar. Pollut. Bull. 16: 227-231

Rosenberg, R., Loo, L.-O. (1986). Effects of eutrophication on benthos in the Laholm Bay, the Kattegat and the Skagerrak. In: Rosenberg, R. (ed.) The eutrophication in Kattegat. Swedish Environmental Protection Board. Report No. 3272: 118-127 (Swedish)

Rosenberg, R., Loo, L.-O. (1988). Marine eutrophication induced oxygen deficiency: effects on soft bottom fauna, western Sweden. Ophelia 29: 213-225

Schmidt-Nielsen, K. (1975). Animal physiology: adaptation and environment. 3rd edn. 1987. Cambridge University Press, Cambridge, p. 177-222

Senkbiel, E. G., Wriston, J. G. Jr (1981). Haemocyanin synthesis in the american lobster, Homarus americanus. Comp. Biochem. Physiol. 683: 163-171

Simpson, A. C. (1965). Variation in catches of Nephrops norvegicus at different times of the day and night. Rapp. P.-v. Réun. Cons. perm. int. Explor. Mer 156: 186-189

Smith, C. J. (1988). Effects of megafaunal/macrofaunal burrowing interactions on benthic community structure. Ph.D. thesis, University of Glasgow

Sundberg, J., Rydberg, L. (1986). Monthly observations of salinity, oxygen and nutrients in a Swedish coastal area during the years 1982-1985. Inst. of Oceanography. Univ. Gothenburg. Rep. No 47: 1-30

Svansson, A. (1975). Physical and chemical oceanography of the Skagerrak and Kattegat. Fishery Board of Sweden Inst. Mar. Res. 1. 1-88

Thomas, H. J., Davidson, C. (1962). The food of the Norway lobster. Mar. Res. 3: 1-15

Thomas, H. J., Figueiredo, M. J. (1965). Seasonal variation in the catch composition of the Norway lobster, Nephrops norvegicus (L.) around Scotland. J. Cons. int. Explor. Mer 30: 75-85

Uglow, R. F. (1969). Haemolymph protein concentrations in portunid crabs - II. The effects of imposed starving on Carcinus maenas. Comp. Biochem. Physiol. 31: 959-967

Windom, H. L., Smith, R. G. (1979). Copper concentrations in surface waters off the southeastern Atlantic coast, USA. Mar. Chem. 7: 157

Zar, J. H. (1984). Biostatistical Analysis. 2nd edn. PrenticeHall Inc., Englewood Cliffs

Manuscript first received: January 16, 1990

Revised version accepted: July 25, 1990 